\title{
The Comparison of Innovations in Slovakian Forestry between 2002 and 2010 - a Shift to Multifunctionality?
}

\author{
Zuzana Sarvašová ${ }^{1,2}$, Jaroslav Šálka ${ }^{3}$, Zuzana Dobšinská ${ }^{3}$, \\ Miroslav Kovalčík ${ }^{1}$
}

\footnotetext{
${ }^{1}$ National Forest Centre - Forest Research Institute Zvolen, T.G. Masaryka 22, SK-960 02 Zvolen, Slovakia

${ }^{2}$ Czech University of Life Sciences Prague, Kamýcká 961/129, CZ-165 00 Prague, Czech Republic

${ }^{3}$ Technical University in Zvolen, . G. Masaryka 2117/24, SK-960 53 Zvolen, Slovakia

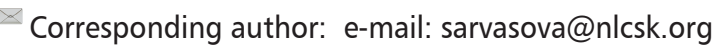

Citation:

SARVAŠOVÁ Z, ŠÁLKA J, DOBŠINSKÁ Z, KOVALČíK M 2014 The Comparison of Innovations in Slovakian Forestry between 2002 and 2010 - a Shift to Multifunctionality? South-east Eur for 5 (2): 125-134. DOI: http://dx.doi. org/10.15177/seefor.14-11

Received: 25 Jun 2014;

Accepted: 23 Sep 2014;

Published online: 7 Oct 2014

\begin{abstract}
Background and Purpose: Innovations play an important role in multifunctional forestry due to changing demands for forest goods and services. The multifunctionality can be a result of a joint provision of several outputs from individual forest holding or specialized forest activities. The goal of this paper is to make a comparative analysis from data obtained in two surveys in 2002 and 2010 related to innovations in forest enterprises. The main focus was on ownership, size, and management strategy of forest.
\end{abstract}

Materials and Methods: The paper presents the results of two surveys on innovation in the years 2002 and 2010 with more than 250 representatives - owners/managers of Slovak forest enterprises. The questionnaire in 2002 was sent out by regular mail in the random sample of 1072 forest owners and managers. The response rate was $25 \%$ (in total 279 respondents). The response rate in 2010 was $37 \%$, and the number of valid responses was 254 . The willingness of forest managers to implement innovation was evaluated in the context of different sizes of forest holdings, management strategies and property conditions. Log linear statistics models (Pearson Chi-square) were applied using the software Statistica for data analysis and Microsoft Excel to present the results.

Results: This paper presents the development of innovations in order to reach the multifunctionality on the case of Slovakian forestry. Product innovations have doubled from $17 \%$ in 2002 to $34 \%$ in 2010. Large-sized holdings are significantly $(p<0.01)$ more engaged in innovation and are offering new products. The highest overall innovation activity is revealed in the state-owned enterprises, intermediary in the municipal forests, and the lowest in the private holdings. Forest managers who realized the benefits of innovation were "profit increasing" oriented. Forest managers who did not realize the benefits of implementing innovations preferred conservative management goals - the capital maintenance. The innovative behaviour of managers depends significantly on forest managers' goals and their strategy $(p<0.05)$. The comparison between the two periods shows that innovation activity has increased from technological innovation to products and services. Wood still remains the main product of forest holdings, but compared to 2002, the importance of bio energy becomes visible.

Conclusions: Results show that innovation activity has increased during the time. There was a shift towards innovation from 2002 to 2010 which is visible in the successful innovation cases.

Keywords: forestry, non-wood forest products, forest managers, innovations 


\section{INTRODUCTION}

Innovation is vital to economic growth and development. Through innovation, new products are introduced into the market, new production processes are developed and introduced, and organizational changes are made [1].

Innovations in this paper is understood according to the definition in Oslo Manual as "[...] the implementation of a new or significantly improved product (goods or service), or process, a new marketing method, or a new organizational method in business practices, workplace organization or external relations" [2]. Applied to forestry, it includes those changes within forest holdings, which are either new to the firm or new to the market. Innovations that are new to the firm are innovations that can be well established in the market already, nevertheless, they are newly introduced in the portfolio of products of a certain firm $[3,4]$.

Innovation and innovation policy in forestry was investigated by different projects on national, regional and EU level. Rametsteiner et al. [1] summarized the collected results from sectoral network approach used in the European Forest Institute Project Centre INNOFORCE. Currently, the regional cross-disciplinary approach in innovation research is supported by the Central-East European Regional Office of the European Forest Institute (EFICEEC). COST Action E51 on "Innovation and Development Policies for Forest Sector" from 2006 to 2010 contributed significantly to the study of innovation policies and processes in the forest sector in Europe. Innovation plays an important role in multi-functional forestry due to changing of demands for forest goods and services [5].
Multifunctionality is internationally discussed by international organizations, such as the Food and Agriculture Organization $[6,7]$, the Organization for Economic Cooperation and Development $[2,8]$ and the European Union [9]. Within the European Union, the term multifunctionality is discussed against the background of changing frame conditions for agricultural and forestry production. This differentiation of usage demands and perceptions coincides with a different understanding of agriculture and forestry being responsible for the management of rural area and thus pre-setting an aspect of multifunctional land use [10]. As a result, forestry is put less into the context of the production of timber (commodity-outputs), but rather into the context of non-commodityoutputs (ecosystems functions and services). On-going changes in environmental and socioeconomic conditions are affecting the balance of desired ecosystem services and functions provided by all European forests. Timber is still a dominant product, but the multifunctionality requires development of other services or new forests' products. .

Achieving multifunctionality of European forests will depend on new ecosystem services and products, as well as on socio-economic, ecological and ownership conditions. In order to achieve the multifunctionality via new nonwood forest products and services, forest owners and managers have to implement innovations in their forest holdings.

Multifunctional forestry goals are presented in the National Forest Program of the Slovak Republic [11]. The basic information about Slovak forestry are provided in Table 1, which captures data about the area and ownership of Slovak forestry [12].

TABLE 1. Slovak forestry in 2010 (source [12])

\begin{tabular}{cccccc}
\hline $\begin{array}{c}\text { Forest } \\
\text { land area } \\
\text { (ha) }\end{array}$ & $\begin{array}{c}\text { Public } \\
\text { forests } \\
\text { (ha) }\end{array}$ & $\begin{array}{c}\text { Private } \\
\text { forests } \\
\text { (ha) }\end{array}$ & $\begin{array}{c}\text { Not restituted } \\
\text { forest land } \\
\text { (ha) }\end{array}$ & $\begin{array}{c}\text { No. of subjects that } \\
\text { manage forests }\end{array}$ & $\begin{array}{c}\text { Average } \\
\text { tenure } \\
\text { (ha) }\end{array}$ \\
\hline 1938904 & 974181 & 785632 & 179091 & 7051 & 8.93 \\
\hline
\end{tabular}


In the forest sector policy, as in other sectoral policy discussions, innovation is specifically discussed in the context of improving the competitiveness of sustainable forestry vis-àvis other sectors of the economy and vis-à-vis the forest sectors of other countries $[3,4,13$ $16]$.

Forestry is an important source of income for forest owners and for employees in rural areas. The future of the people, who make a living in rural areas from forestry, will considerably depend on how individuals and institutions react in view of the changes, how forest owners and managers obtain new knowledge and put it into practice in forestry, and how institutions, especially forest administration, extension services, fo-rest research or other institutions best deal with emerging changes. The restructuring of forestry and the development of wood prices tend to have a negative impact on em-ployment. To compensate for the negative impacts, product and service innovations based on the multifunctional use of forest and the efficient use of the growing stock of wood can provide new opportunities for rural employment [17].

The main goal of this paper is to make a comparative analysis from the data obtained in two surveys conducted in 2002 and 2010 related to innovations in forest enterprises. The main focus was on the ownership, size, and management strategy of the forest.

\section{MATERIAL AND METHODS}

The data collection was based on a questionnaire using closed and open questions, which were focused on the following areas: innovation activity and behaviour, fostering and impeding factors to innovation, successfulness of innovation, product mix and market expectation of forest owners and managers for the future. We conducted surveys in 2002 and 2008 using the questionnaire of the project INNOFORCE from 2002 [5] on the Survey on innovations and entrepreneurship of forest holdings. The questionnaire in $\mathbf{2 0 1 0}$ was slightly adapted on current conditions and this allowed the comparison with the results from INNOFORCE surveys and current situation. The minimum requirement for an innovation in the survey was that the product, process, marketing me-thod or organizational method had to be new to the forest enterprise and that it has been implemented in the market during the last 3 years. The main features of the innovative entrepreneurship towards multifunctional forestry management included an autono-mous activity of forest holdings, creativity, target-orientation, initiative, novel approaches in nonstandard situations, ability to make decisions in uncertain situations, and the wi-llingness to take risk.

Respondents were chosen randomly from the national forest holdings database, maintained by the National Forest Centre. The 26 regional enterprises of the State enterprise "Forests SR" and non-state forest holdings represented the basic population of the survey. Their owners and managers who are responsible for the management and product or process-related decisions, were the target information sources. Questionnaires were sent by regular mail and by email to the state and non-state forest holdings during the years 2002 and 2010 respectively. The questionnaire in 2002 was sent out by regular mail in the random sample of 1072 forest owners and managers. The response rate was $25 \%$ (in total 279 respondents). The response rate in 2010 was $37 \%$, and the number of valid responses was 254, of which 76 were from public holdings and 178 from private holdings (including community and church forests). A summary is presented in Table 2. The questionnaire was broadly focused on innovation, but for the purposes of this study we chose only the evaluation of innovation activity described by the willingness of forest managers to innovate. Data was analysed by descriptive statistic methods. Standard contingency method was used to analyse innovation behaviour in dependence on various variables. Loglinear statistics models (Pearson Chi-square) were applied using the software 
TABLE 2. Structure of respondents according to forest ownership

\begin{tabular}{cccccccc}
\hline & Total sent & Received & State & Municipal & Communal & Private & Church \\
\hline 2002 & 1072 & 279 & 20 & 21 & 210 & 24 & 4 \\
2010 & 693 & 254 & 21 & 55 & 164 & 14 & 0 \\
\hline
\end{tabular}

Statistica for data analysis and Microsoft Excel for the presentation of results. The following research questions were formulated:

1. Are there any differences in innovations from 2002 to 2010 ?

2. How does holding's size influence innovations?

3. How does ownership influence innovation in forest enterprises?

4. Which are the appropriate management strategies to implement innovations?

\section{RESULTS AND DISCUSSION}

\section{Progress in Innovation Activity}

The types of innovations, which were successful, can be divided into three categories: products, services and technological or organizational innovations (T-O-I). Technological and organizational innovations hold the biggest share on successful innovations in 2002 (56 \%) compared with $38 \%$ in 2010. Higher intensity of technological innovations in 2002 could be explained by the continuing transition to the market economy, where technological innovations are undertaken continuously as new technological means or principles become available. As the transformation process in Slovakia continues, innovations become more product-oriented. Product innovations have doubled from $17 \%$ in 2002 to $34 \%$ in 2010 .

In Table 3 we can see the number of forest holdings that implemented one or more successful innovations during the period of 3 years before the survey. The innovation activity has significantly increased in 2010 ( $p<0.01$ ).

\section{Forest Holdings Lager then $\mathbf{5 0 0}$ ha Innovate More}

Table 4 provides the overview of small and large forest holdings according to their innovation activity. The results are related to the second research question, and they show a difference between smaller and larger forest holdings in innovation activity. Small forest holdings (manage less than 500 ha of forest land) prefer round wood to other products. Some of their managers stated that they do not offer any products, because they manage the forest for self-consumption (17 managers in 2002 and 21 managers in 2010). Largesized holdings are significantly $(p<0.01)$ more engaged in innovation and in offering new products and services.

TABLE 3. Impact of time on the willingness to innovate

\begin{tabular}{cccc}
\hline Innovation & No & Yes & Total \\
\hline Survey 2002 & 183 & 86 & 269 \\
Survey 2010 & 145 & 114 & 259 \\
Total & 328 & 200 & 528 \\
\hline Pearson Chi-square & Chi-sqr & df & p \\
\hline & 110.2159 & 4 & 0.000000 \\
\hline
\end{tabular}


TABLE 4. Impact of forest holding size on innovation activity*

\begin{tabular}{cccc}
\hline Innovation & No & Yes & Total \\
\hline Small forest holdings & 247 & 67 & 314 \\
Large forest holdings & 81 & 133 & 214 \\
Total & 328 & 200 & 528 \\
\hline Pearson Chi-square & Chi-sqr & df & p \\
\hline & 14.15794 & 4 & 0.006808 \\
\hline
\end{tabular}

* presented data represent results from joined dataset (2002 and 2010 survey)

Nowadays, other wood products as Christmas trees and seedlings, game, non-wood products and rental services have got a bigger share in the forest product mix. Recreation and tourism gained the most important role (Figure 1).

The positive shift towards non-wood product offer is a result of adopted strategic documents (such as National Forest Program, Rural Development Program) that emphasize the principle of sustainable forest management and the importance of the forestry sector in rural development. Supporting measures (financial, informational) for diversifications exist for all types of forest holdings at a national level, but they are partly funded from EU resources.

\section{Public Forest Holdings Innovate Easily}

The type of ownership appeared to be important for the innovation activity of forest holdings. The ownership structure in Slovakia is rather complicated due to restitution processes in the past decades. We can identify the following categories of forest holdings: private (individual or corporate owned), community (shared ownership by individual persons), church, municipal and state. The state and municipal forests are evaluated as public forests according to the Forest Europe classification [18]. The empirical observations show that the highest overall innovation activity is revealed in the state-owned enterprises, intermediate in the municipal forests, and lowest in the

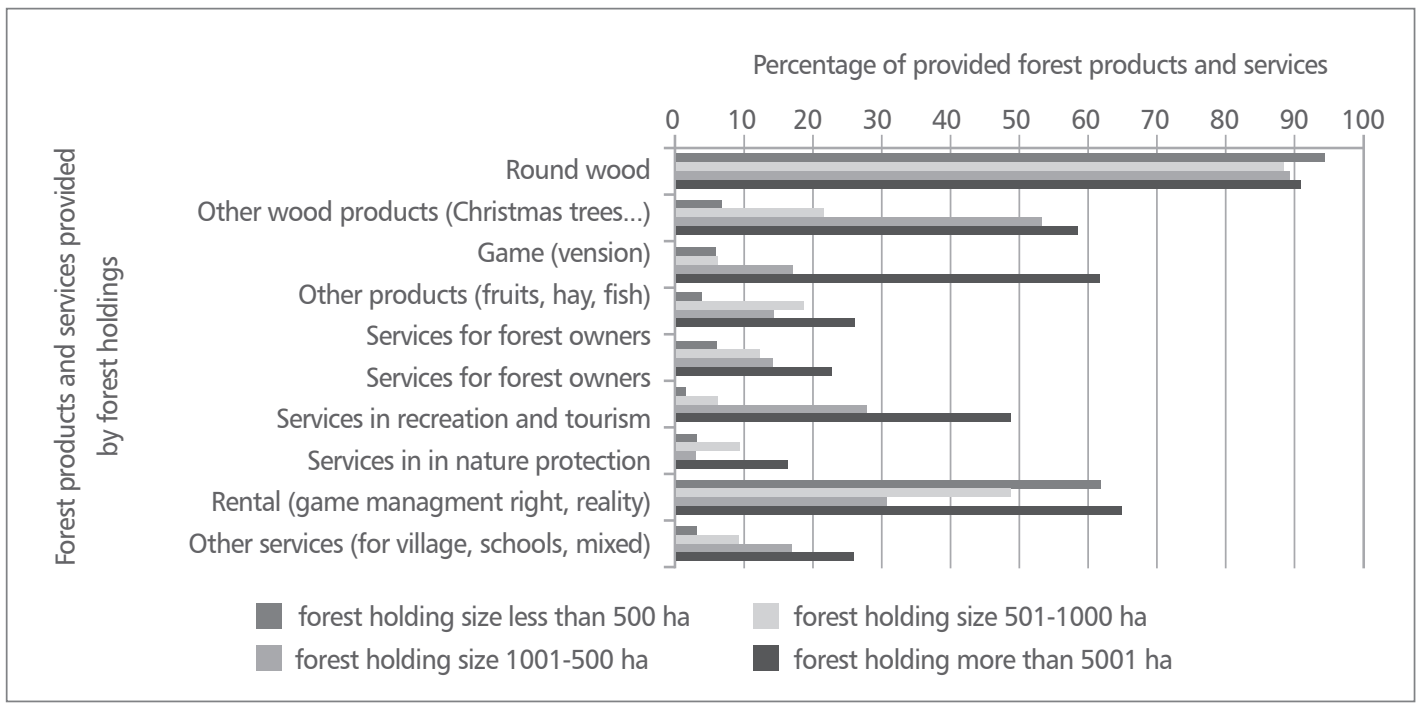

FIGURE 1. The product mix in Slovakia 2010 
TABLE 5. Impact of forest ownership structure on innovation activity*

\begin{tabular}{cccc}
\hline Innovation & No & Yes & Total \\
\hline Public holdings & 41 & 95 & 136 \\
Private holdings & 287 & 105 & 392 \\
Total & 328 & 200 & 528 \\
\hline Pearson Chi-square & Chi-sqr & df & p \\
\hline & 9.738639 & 4 & 0.045068 \\
\hline
\end{tabular}

* presented data represent results from joined dataset (2002 and 2010 survey)

private holdings (owned by land associations and individuals) (Table 5). This can be explained by the lack of disposable financial resources for the non-state forest owners [19].

In the second survey, $67 \%$ of state and municipal forest managers reported the implementation of one or more innovations. This proportion is significantly higher than random $(p<0.05)$. Forest managers were also asked to name the most successful innovation. The responses showed that the innovations concerning biomass for energy purposes (e.g. wood chips supply) have higher success than other products. This is only a small step away from timber production, but very positive in accordance with the aspirations on the utilization of alternative energy resources in the EU. Slovak forest owners and managers have also recognized this opportunity.

\section{The Innovation Towards Multifunctio- nality Needs Appropriate Management Strategies}

There is a logic relation between innovation activities and management goals. Increasing of profit and productivity can't be achieved without an increased effort oriented to improve, modernize and rationalize forest production. The management goal is therefore an important motivating factor for innovative behaviour. Forest managers were asked about their goals for forest management: 1 . increasing profit, 2. maintaining capital and 3. abandoning of forest management.

In 2002, in non-state forests the goal of maintaining the capital dominated, namely in municipal forests (62\%) and in shared forest holdings (52\%). The situation was the same in 2010 , the majority of forest managers (52\%) stated that they managed the forest with the goal to maintain capital. However, the share of mangers that managed state forests with the goal to increase profit decreased from $59 \%$ to $26 \%$.

A more detailed analysis was focused on the means how forest managers want to achieve these goals:

1. specialization to one product production (timber),

2. offer of various products,

3. more intensive evaluation of products and/or services,

4. leaving out and/or decreasing the extent of works (within the framework of forest management plan),

5. rationalization, costs reduction,

6. co-operation in associations, mechanization centres,

7. by buying additional forests,

8. sale of (non-state only) forest,

9. maintenance of up-to-now way of work,

10. other means (e.g. improvement of forest roads).

Surveys showed that there are two major strategies according to the means how to achieve selected management goals. Conservative strategy is focused on "business as usual" (9), specialization on timber production (1), decreasing extent of works within the framework of forest management plan (4) and reduction of timber production costs (5). 
Modern strategy is described by diversification (2), improved marketing of non-wood products and services (3), cooperation with non-wood products and services introduction (6) and expansion of property for new products and services (7). However, the share of innovation in forest holdings in combination with both management strategies seems to be the most successful. Innovation activity in relation to management strategy is presented in Table 6. Only a few small forest owners or managers responded that their actual aim was to sell property or abandon forest management (2 \% in 2002 and $3 \%$ in 2010).

Forest managers who realized the benefits of innovation were "profit increasing" oriented. Forest managers who did not realize the benefits of innovation preferred conservative management goals - the capital maintenance. According to the results it could be summarized that the willingness to implement innovation is in relation with the chosen management strategy (Table 7). The innovative behaviour of managers depends significantly on forest managers' goals and their strategy $(p<0.05)$.

The essential changes in the Central and Eastern European countries in the nineties of the past century resulted in the introduction of technological and organizational innovations into forest management. At present, the most implemented types of innovations are new products and services. This fact can be explained by the accession of many Central and Eastern European countries to the European Union in

TABLE 6. Management strategy and number of implemented innovations

\begin{tabular}{cccccccccc}
\hline \multirow{2}{*}{ Survey } & Strategy & \multicolumn{2}{c}{ Innovations } & \multicolumn{2}{c}{ Category of innovation } & \multicolumn{2}{c}{$\begin{array}{c}\text { Relative proportion of } \\
\text { innovation }\end{array}$} \\
\cline { 3 - 9 } & & no & yes & Products & Services & $\begin{array}{c}\text { Tech. } \\
\text { Org. }\end{array}$ & Products & Services & $\begin{array}{c}\text { Tech. } \\
\text { Org. }\end{array}$ \\
\hline \multirow{2}{*}{2002} & n.a. & 10 & 0 & 0 & 0 & 0 & - & - & - \\
& Conservative & 86 & 20 & 12 & 10 & 23 & 26.7 & 22.2 & 51.1 \\
& Modern & 27 & 11 & 10 & 8 & 10 & 35.7 & 28.6 & 35.7 \\
& Combination & 59 & 54 & 61 & 55 & 77 & 31.6 & 28.5 & 39.9 \\
\hline \multirow{2}{*}{2009} & n.a. & 6 & 1 & 1 & 2 & 1 & 25.0 & 50.0 & 25.0 \\
& Conservative & 84 & 26 & 10 & 14 & 28 & 19.2 & 26.9 & 53.8 \\
& Modern & 22 & 27 & 33 & 18 & 25 & 43.4 & 23.7 & 32.9 \\
& Combination & 32 & 59 & 64 & 54 & 64 & 35.2 & 29.7 & 35.2 \\
\hline
\end{tabular}

n.a. stands for forest managers that did not choose any of the management strategy

TABLE 7. Impact of management strategy on innovation activity*

\begin{tabular}{cccc}
\hline Innovation & No & Yes & Total \\
\hline n.a. & 17 & 2 & 19 \\
Conservative strategy & 171 & 47 & 218 \\
Modern strategy & 50 & 39 & 89 \\
Combination of strategies & 92 & 114 & 206 \\
Total & 330 & 202 & 532 \\
\hline Pearson Chi-square & Chi-sqr & df & p \\
\hline
\end{tabular}

* presented data represent results from joined dataset (2002 and 2010 survey)

n.a. stands for forest managers that did not choose any of the management strategy 
2004 which is linked with the possibility to use the financial means from the European funds for diversification of forestry activities. The interests of forest owners and the whole society were reoriented on the offer expansion of new services and new products in relation to ecosystem services [20].

Pudivítrová and Jarský [21] reported no increase in the share of innovative behaviour of foresters in the Czech Republic in comparison with the situation 10 years ago, although they found significant changes in the structure of implemented innovations towards new products.

Slee [22] pointed out that when we are talking about multifunctional forestry, we need to think about scale and temporal issues. Locally demanded functions may differ from national demands and current preferences do not need to indicate preferences in the long run. This progress is visible by the market expectations of forest owners in 2002, when, besides wood, drinking water was also considered as the main gain that forests could provide. Changes are visible and are in line with the implementation of European policy targets in the energy policy. In 2010, beside the above-mentioned goods, recreation, environmental services and carbon sequestration were also prioritized. The climate change policy and the supporting measures for biomass use as an alternative energy resource on the global level and in Europe, gained a significant role of bio energy services in forestry practice. Our research supports these findings. According to the survey in Slovakia, it is assumed that an increase of importance of drinking water and bio energy will be visible in the future (Figure 1).

According to Nastase et al. [14] the evidence from Romania show that the innovation in rural areas is about "doing traditional activities in a new way", and all innovations are strongly linked with social processes such as creation of networks, strengthening of local identities, and creation and transfer of knowledge.

\section{CONCLUSIONS}

Results show that the innovation activity has increased during the observed timeframe. This correlates with the forest policy which aims to support multifunctional forestry by implementing new services and products. Small forest holdings prefer round wood to other products. Large-sized holdings are more engaged in innovation and in offering new products. Type of ownership appeared to be an important factor for the innovation activity of forest holdings. State and municipal forest enterprises are more inclined to innovation than private and communal ones.

Overall it can be concluded, that there was a shift towards innovation from 2002 to 2010 which is visible in the successful innovation cases. Forest managers are innovative in accordance with the strategic objective 4 of the National Forest Programme of the Slovak Republic: Increasing longterm competitiveness and priorities strive for increased competitiveness and economic viability of multifunctional forestry. They offer more non-wood forest products, support the use of forest biomass to produce energy and cooperate more in order to maintain and foster the ecosystem services.

\section{Acknowledgements}

This work was supported by the Slovak Research and Development Agency under the contract No. APVV-0057-11 and Czech National Agency for agriculture development No. QJ1220313. The paper is the result of the project implementation: Extension of the Centre of Excellence "Adaptive Forest Ecosystems", ITMS: 26220120049, supported by the Research \& Development Operational Programme funded by the ERDF.

We also would like to thank two anonymous reviewers who helped to improve this manuscript. 


\section{REFERENCES}

1. RAMETSTEINER E, WEISS G, KUBECZKO K 2005 Innovation and Entrepreneurship in Forestry in Central Europe. European Forest Institute, Research Report, Volume 19. Brill. Leiden, Netherlands, $179 p$

2. OECD 2005 Oslo Manual: Guidelines for Collecting and Interpreting Innovation Data, $3^{\text {rd }}$ Edition. Organisation for Economic Cooperation and Development, Statistical Office of the European Communities. DOI: http://dx.doi. org/10.1787/9789264013100-en

3. KUBECZKO K, RAMETSTEINER E 2002 Innovation and Entrepreneurship - A New Topic for Forest related Research? Discussion Paper P/2002-1, Institute of Forest Sector Policy and Economics, Wien, Austria

4. RAMETSTEINER E 2000 Innovation and Entrepreneurship Research in Forestry Definitions. Key Questions and Measurement Approaches used for the EFI Regional Project Centre Innoforce; Background Paper 1, EFI RPC Innoforce, BOKU Vienna, Austria

5. WEISS G, PETTENELLA D, OLLONQVIST P, SLEE B 2011 Innovation in Forestry - Territorial and Value Chain Relationships. CABI, London, UK, 331 p. DOI: http://dx.doi.org/10.1079/9781845936891.0000

6. FAO 2000 Cultivating Our Futures. Taking Stock of the Multifunctional Character of Agriculture and Land. Food and Agriculture Organization of the United Nations. URL: http://www.fao.org/3/ax2776e/X2776E00.htm (15 July 2013)

7. FAO 2000 Multifunctional Character of Agriculture and Land. 21th FAO Regional conference for Europe, Porto, Portugal, 24-28 July 2000. Food and Agriculture Organization of the United Nations. URL: http://www.fao.org/do-crep/ meeting/X7073E.htm (15 July 2013)

8. OECD 2001 Multifunctionality: Applying the OECD Analytical Framework Guiding Policy Design. Workshop, Paris, France, 2-3 July 2001. The Organisation for Economic Co-operation and Development (OECD). URL: http://www1.oecd. org/agr/mf/index.htm (22 January 2014)

9. GLEBE T 2003 Multifunctionality: How "Green" is the "European Model of Agriculture?" Discussion Paper 01-2003, Environmental Economics, Resource Economics and Agricultural Policy Research Group, Technische Universität München, Germany, $29 p$
10. WIGGERING H, Mueller K, WERNER A, HELMING K 2003 The concept of multifunctionality in sustainable land development. In: Helming K, Wiggering $\mathrm{H}$ (eds) Sustainable Development of Multifunctional Landscapes. Springer-Verlag. Berlin Heidelberg New York, pp 3-18. DOI: http:// dx.doi.org/10.1007/978-3-662-05240-2_1

11. MORAVČ́́K M, NOVOTNÝ J, TOMA P 2007 National forest programme of the Slovak republic. (Národný lesnícky program Slovenskej republiky) (in Slovak). 1. vyd. Bratislava, Zvolen: Ministerstvo pôdohospodárstva SR, Národné lesnícke centrum - Lesnícky výskumný ústav Zvolen.

12. GREEN REPORT 2011. Report on the status of Foresty in the Slovak Republic. Bratistava: Ministry of Agriculture of the Slovak Republic in cooperation with the National Forest Centre Forest Research Institute Zvolen. URL: http://www. mpsr.sk/index.php?navID=123\&id=5250 (5 May 2013)

13. WEISS G, RAMETSTEINER E 2005 The role of innovation system in non-timber forest products and services development in Central Europe. Economic Studies 14 (1): 23-36

14. NASTASE C, CHASOVSCHI C, LUPAN M 2008 Investment and innovation in support of rural development in Romania. Annales Universitatis Apulensis Series Oeconomica 2 (10): $15 \mathrm{p}$

15. NYBAKKE, CRESPELL P, HANSEN E, LUNNAN A 2009 Antecedents to forest owner innovativeness: An investigation of the non-timber forest products and services sector. Forest Ecol Manag 257 (2): 608-618. DOI: http://dx.doi.org/10.1016/j. foreco.2008.09.040

16. SIKORA A T, NYBAKK E 2012 Rural development and forest owner innovativeness in a country in transition: Qualitative and quantitative insights from tourism in Poland. Forest Policy Econ 15: 3-11. DOI: http://dx.doi.org/10.1016/j. forpol.2011.09.003

17. RAMETSTEINER E, WEISS G 2004 Innovation and Entrepreneurship in Forestry in Central Europe. Draft paper presented at "Sustain Life - Secure Survival II" Conference, Prague, Czech Republic, 22-25 September 2004. URL: https://innoforce. boku.ac.at/publications/l\&E_ForestryCE_Prag04. pdf on 20.9.2012 12p (5 May 2013). 